\title{
STRATEGI PENDIDIKAN AGAMA ISLAM DALAM MEWUJUDKAN LINGKUNGAN SEKOLAH YANG RELIGIUS DI SMAN 3 BANDUNG
}

\author{
ISLAMIC RELIGIOUS EDUCATION STRATEGY IN \\ CREATING A RELIGIOUS SCHOOL ENVIRONMENT IN \\ SMAN 3 BANDUNG
}

\author{
Sumarsih Anwar \\ Balai Litbang Agama Jakarta \\ Jl. Rawa Kuning No. 6 Pulo Gebang Cakung Jakarta Timur \\ Email: sumarsih.anwar@yahoo.com
}

\begin{abstract}
Religious education is intended to realize the Indonesian human resources that are faithful and devoted to God the Almighty and have the advantage of noble morality which is a necessity in education and learning. To achieve such a lofty goal, it would require a variety of efforts or learning strategies, one of which is a Islamic Education study (PAI), as an attempt to create a religious school environment. The study was conducted at SMAN 3 Bandung, with the aim of describing: 1) Perception of the principal on PAI, 2) perceptions of students about PAl, and 3) Strategies of PAI in creating a religious school environment. The study result shows that the principal holds very positive view on PAl, which is manifested in the form of policy towards the implementation of PAl learning in intra-curricular and extracurricular activities. One of PAI learning strategies adopted is to integrate extracurricular activities (mentoring) and PAI in a program called the MT-PAI (Integrated Mentoring Islamic Education). The activity works well because of the positive student perceptions on PAI that $P A l$ is quite interesting and easy to learn and the material is easy to be practiced in everyday life.
\end{abstract}

Keywords: Strategy, Perception, Islamic Religious Education, Religious

\begin{abstract}
Abstrak
Pembelajaran pendidikan agama dimaksudkan untuk mewujudkan sumber daya manusia (SDM) Indonesia yang beriman dan bertakwa kepada Tuhan Yang Maha Esa serta memiliki keunggulan akhlakul karimah, ini merupakan suatu keniscayaan dalam pendidikan dan pembelajaran. Untuk mewujudkan tujuan yang mulia tersebut, maka diperlukan berbagai upaya ataupun strategi pembelajaran, salah satunya adalah strategi pembelajaran Pendidikan Agam Islam (PAI), sebagai upaya untuk mewujudkan lingkungan sekolah yang religius. Penelitian dilakukan di SMA N 3 Bandung, dengan tujuan untuk mendeskripsikan tentang: 1) Persepsi pimpinan sekolah tentang PAI, 2) persepsi siswa tentang $P A l$, dan 3) Strategi $P A I$ dalam mewujudkan lingkungan sekolah yang religius. Hasil dari penelitian adalah, bahwa pimpinan (kepala sekolah) berpandangan sangat positif terhadap PAl, yang diwujudkan dalam bentuk kebijakan terhadap penyelenggaraan pembelajaran PAI dalam kegiatan intrakurikuler dan ekstrakurikuler. Salah satu strategi pembelajaran PAI yang diterapkan adalah dengan mengintegrasikan antara kegiatan ekstrakurikuler (mentoring) dengan mata pelajaran PAl yang disebut dengan MT-PAI (Mentoring Terintegrasi Pendidikan Agama Islam). Kegiatan tersebut dapat berjalan dengan baik, karena diimbangi persepsi siswa yang positif terhadap PAl, bahwa PAl cukup menarik dan mudah untuk dipelajari, dan materinya mudah dipraktikkan dalam kehidupan sehari-hari.
\end{abstract}

Kata Kunci: Strategi, Persepsi, Pendidikan Agama Islam, Religius

Naskah diterima 27 Februari 2015. Revisi pertama, 15 Maret 2015. Revisi kedua, 21 Maret 2015 dan revisi terahir 29 April 2015 


\section{PENDAHULUAN}

Agama merupakan bagian yang tidak dapat dipisahkan dalam kehidupan, baik sebagai makhluk individu maupun sebagai anggota masyarakat. Sepanjang sejarahnya, gerak langkah serta kehidupan sosial masyarakat bangsa Indonesia telah dijiwai oleh kehidupan yang religius. Keberhasilan dan kebahagiaan yang hakiki tidak dapat dicapai tanpa agama. Keberhasilan materi dan kesuksesan serta prestasi duniawi bukanlah satu-satunya yang menjadi dambaan hidup, namun demikian melalui penghayatan yang mendalam dan pendekatan diri kepada Tuhan Yang Maha Esa kesuksesan itu menjadi benar-benar bermakna.

Agama memiliki peran yang amat penting dalam kehidupan umat manusia. Agamamenjadipemandudalammewujudkan suatu kehidupan yang bermakna, damai dan bermartabat. Menyadari betapa pentingnya peranan agama bagi kehidupan umat manusia, maka internalisasi nilai-nilai agama dalam kehidupan setiap pribadi menjadi sebuah keiscayaan, yang ditempuh melalui pendidikan baik pendidikan di lingkungan keluarga, sekolah maupun di masyarakat.

Pendidikan agama dimaksud untuk meningkatkan potensi spiritual dan membentuk peserta didik agar menjadi manusia yang beriman dan bertakwa kepada Tuhan Yang Maha Esa dan berakhlak mulia, yang mencakup etika, budi pekerti dan moral sebagai perwujudan dari pendidikan agama. Penyelenggaraan pendidikan agama dimaksudkan untuk mewujudkan sumber daya manusia (SDM) Indonesia yang beriman dan bertakwa kepada Tuhan Yang Maha
Esa serta memiliki keunggulan akhlakulkarimah, ini merupakan suatu keniscayaan dalam pendidikan dan pembelajaran. Tidak diragukan lagi bahwa untuk mencapai tujuan itu, Pendidikan Agama (Islam) merupakan suatu faktor yang sangat penting serta keberadaannya sangat berperan untuk masa depan kehidupan bangsa serta memiliki posisi yang strategis.

Peningkatan potensi spiritual mencakup pengamalan, pemahaman, penanaman nilai-nilai keagamaan dalam kehidupan individual atau kolektif kemasyarakatan yang bertujuan pada optimalisasi berbagai potensi yang dimiliki manusia dalam mengaktualisasikan harkat dan martabatnya sebagai makhluk Tuhan.

Studi ini lebih difokuskan pada strategi Pendidikan Agama Islam (PAI) dalam mewujudkan sekolah yang religius, lingkungan sekolah yang diwarnai nilai-nilai agama baik dalam proses pembelajaran maupun dalam kehidupan sehari-hari di sekolah. Tujuan tulisan ini adalah untuk mendeskripsikan tentang: 1) Persepsi pimpinan sekolah tentang PAI, 2) persepsi siswa tentang PAI, dan 3) Strategi PAI dalam mewujudkan lingkungan sekolah yang religius.

\section{Kerangka Konseptual}

\section{Strategi}

Dalam Kamus Besar Bahasa Indonesia, disebutkan bahwa yang dimaksud dengan strategi adalah rencana yang cermat mengenai kegiatan untuk mencapai sasaran khusus. ${ }^{1}$ Dalam konteks pembelajaran,

${ }^{1}$ Departemen Pendidikan dan Kebudayaan. 2003. Kamus Besar Bahasa Indonesia. Jakarta: Balai Pustaka, h. 
Akhmad Sudrajat membagi menjadi 4 (empat) unsur, yaitu: 1) Menetapkan spesifikasi dan kualifikasi tujuan pembelajaran yakni perubahan profil perilaku dan pribadi peserta didik, 2) Mempertimbangkan dan memilih sistem pendekatan pembelajaran yang dipandang paling efektif, 3) Mempertimbangkan dan menetapkan langkahlangkah atau prosedur, metode dan teknik pembelajaran, dan 4) Menetapkan norma-norma dan batas minimum ukuran keberhasilan atau kriteria dan ukuran baku keberhasilan. ${ }^{2}$ Kemp dalam Wina Sanjaya, sebagaimana dikutip oleh Akhmad Sudrajat, mengemukakan bahwa strategi pembelajaran adalah suatu kegiatan pembelajaran yang harus dikerjakan guru dan siswa agar tujuan pembelajaran dapat dicapai secara efektif dan efisien. ${ }^{3}$

\section{Pendidikan Agama Islam}

Menurut Zuhaerini, pendidikan Agama Islam berarti usaha-usaha secara sistematis dan pragmatis dalam membantu anak didik agar mereka hidup sesuai dengan ajaran Islam. ${ }^{4}$ Menurut Dedeng Rosidin pendidikan Islam adalah proses pengembangan, pemeliharaan, penjagaan, pengurusan, penyampaian ilmu, pemberian petunjuk, penanaman, pembinaan, penyempurnaan, dan perasaan memiliki bagi anak didik baik jasad, akal, jiwa, bakat, potensi maupun perasaan secara berkelanjutan, bertahap,

1092.

${ }^{2}$ Akhmad Sudrajat, dalam https://akhmadsudrajat. wordpress.com/2008/09/12/pendekatan-strategimetode-teknik-dan-model-pembelajaran/, diakses tanggal 12 Mei 2015.

${ }^{3}$ Kemp (Wina Sanjaya), Akhmad Sudrajat, Ibid.

${ }_{4}$ Zuhaerini. 1983. Metodik Khusus Pendidikan Agama. Surabaya: Usaha Nasional, h. 27 menuntut adab-adab tertentu, penuh kasih sayang, penuh perhatian, kelembutan hati, bersahabat, menyenangkan, bijak, mudah diterima, sehingga dapat membaca dan mengkaji sendiri, membentuk kesempurnaan fitrah manusia, beriman dan bertakwa, melahirkan amal saleh, hidup mandiri, dan untuk mencapai ridha Allah SWT. ${ }^{5}$

Berdasarkan uraian di atas, maka dapat disimpulkan bahwa pendidikan agama Islam adalah usaha sadar atau kegiatan yang disengaja dilakukan untuk membimbing sekaligus mengarahkan anak didik menuju terbentuknya pribadi yang utama (insan kamil) berdasarkan nilai-nilai etika Islam dengan tetap memelihara hubungan baik terhadap Allah SWT (hablumminallah) sesama manusia (hablumminannas), dirinya sendiri dan alam sekitarnya.

Yusuf al-Qardhawi memberikan pengertian bahwa pendidikan Islam adalah pendidikan manusia seutuhnya (akal dan hatinya, rohani dan jasmaninya, akhlak dan keterampilannya). Pendidikan Islam menyiapkan manusia untuk hidup, baik dalam keadaan damai maupun perang, dan menyiapkannya untuk menghadapi masyarakat dengan segala kebaikan dan kejahatannya, manis dan pahitnya ${ }^{6}$. Selanjutnya adalah Mujib \& Mudzakir, bahwa yang dimaksud dengan pendidikan Islam adalah sebagai proses transinternalisasi pengetahuan dan nilai Islam kepada peserta didik melalui upaya pengajaran, pembiasaan, bimbingan, pengasuhan, dan

${ }^{5}$ Dedeng Rosyidin. 2009. Konsep Pendidikan Formal Persatuan Islam (Persis). Bandung: tp, h.38

${ }^{6}$ Azra, Azyumardi. 2005. Pendidikan Islam: Tradisi dan Modernisasi Menuju Milenium Baru. Jakarta: Logos Wacana Ilmu, h. 5. 
pengembangan potensi, guna mencapai keselarasan dan kesempurnaan hidup di dunia dan akhirat?.

Menurut Abudin Nata, tujuan pendidikan Islam memiliki ciri-ciri sebagai berikut: 1) mengarahkan manusia agar menjadi khalifah Tuhan di muka bumi dengan sebaik-baiknya, yaitu melaksanakan tugas-tugas memakmurkan dan mengolah bumi sesuai dengan kehendak Allah, 2) mengarahkan manusia agar seluruh pelaksanaan tugas kekhalifahannya di muka bumi dilaksanakan dalam rangka beribadah kepada Allah, sehingga tugas tersebut terasa ringan dilaksanakan, 3) mengarahkan agar berakhlak mulia, sehingga ia tidak menyalahgunakan fungsi kekhalifahannya, 4) membina dan mengarahkan potensi akal, jiwa dan jasmaninya, sehingga ia memiliki ilmu, akhlak dan keterampilan yang semua itu dapat digunakan untuk mendukung tugas pengabdiannya dan kekhalifahannya, dan 5) mengarahkan manusia agar dapat mencapai kebahagiaan hidup di dunia dan akhirat ${ }^{8}$.

Manusia yang dapat memiliki ciri-ciri tersebut, secara umum adalah manusia baik. Atas dasar ini, dapat dikatakan bahwa pada hakikatnya tujuan umum pendidikan Islam adalah terbentuknya manusia yang baik, yaitu manusia yang beribadah kepada Allah, dalam rangka pelaksanaan fungsi kekhalifahannya di muka bumi. Hal ini senada dengan pendapat Ahmad Tafsir, yang menyatakan bahwa tujuan umum pendidikan Islam adalah muslim yang

${ }^{7}$ Abdul Mujib, et al. 2008. Ilmu Pendidikan Islam . Jakarta: Kencana, h. 27

${ }^{8}$ Abuddin Nata. 2001. Peta Keragaman Pemikiran Islam di Indonesia. Jakarta: PT. Raja Grasindo Persada, h. 53. sempurna, atau manusia yang takwa, atau manusia beriman, atau manusia yang beribadah kepada Allah'.

Tujuan pendidikan merupakan faktor yang sangat penting, karena merupakan arah yang hendak dituju oleh pendidikan itu. Demikian pula halnya dengan Pendidikan Agama Islam, yang tercakup mata pelajaran akhlak mulia dimaksudkan untuk membentuk peserta didik menjadi manusia yang beriman dan bertakwa kepada Tuhan Yang Maha Esa serta berakhlak mulia. Akhlak mulia mencakup etika, budi pekerti, atau moral sebagai perwujudan dari pendidikan agama.

Tujuan pendidikan secara formal diartikan sebagai rumusan kualifikasi, pengetahuan, kemampuan dan sikap yang harus dimiliki oleh anak didik setelah selesai suatu pelajaran di sekolah, karena tujuan berfungsi mengarahkan, mengontrol dan memudahkan evaluasi suatu aktivitas sebab tujuan pendidikan itu adalah identik dengan tujuan hidup manusia.

\section{Pesepsi}

Persepsi (perception) adalah proses mengingat atau mengidentifikasikan sesuatu..$^{10}$ Menurut Stephen Robins, persepsi didefinisikan sebagai suatu proses dengan mana individu-individu mengorganisasikan dan menafsirkan kesan indera mereka agar memberimaknakepadalingkunganmereka. ${ }^{11}$

9 Ahmad Tafsir. 2005. Ilmu Pendidikan Dalam Perspektif Islam. Bandung: PT. Remaja Rosdakarya, h.14.

${ }^{10}$ Draver James. 1986. Kamus Psikologi. Jakarta: Bina Aksara, h. 338.

${ }^{11}$ Stephen P. Robins. 1996. Perilaku Orgaisasi (Edisi Bahasa Indonesia, Alih Bahasa Hadyana Pujatmaka). Jakarta: Prenhallindo, h. 124. 
Pendapat lainnya adalah B. Wortman, dkk., pengertian persepsi adalah suatu proses di mana otak menginterpretasikan sensasi yang datang, member perintah dan berarti ("perception, in contrast, is the process whereby the brain interprets the sensation it receives, giving then order and meaning").12 Senada dengan pengertian tersebut adalah definisi dari Jalaluddin Rakhmat, bahwa persepsi adalah pengalaman tentang objek, atau hubungan-hubungan yang diperoleh dengan menyimpulkan informasi dan pesan. Secara singkat persepsi adalah memberikan makna pada stimuli Inderawi (Sensory Stimully). ${ }^{13}$

Sesuaidenganpengertiatentangpersepsi tersebut, maka yang dimaksud dengan persepsi terhadap PAI dalam penelitian ini adalah kemampuan seseorang (dhi. kepala sekolah dan siswa) untuk mengorganisasikan dan menafsirkan terhadap PAI dalam proses pembelajaran di sekolah. Proses persepsi dapat terjadi melalui proses penginderaan, pengalaman berdasarkan pemikiran/pengamatan/pendapat kepala sekolah dan siswa yang melibatkan atensi, ekspektasi dan pengalaman masa lalu.

\section{Religius}

Religius, berasal dari kata kepercayaan kepada Tuhan, kepercayaan akan adanya kekuatan adi kodrati di atas manusia. Religiusitas bersifat keagamaan ${ }^{14}$. Menurut Thontowi, religius berasal dari kata religious

${ }^{12}$ Camille B. Wortman, Elizabeth F.Loftus, Mary E.Marshall. 1985. Psycology. New York: Alfred A.Kniff. Inc., h. 93.

${ }^{13}$ Jalaluddin Rakhmat. 1988. Psikologi Komunikasi. Bandung: Remadja Karya, h. 57.

14 Departemen Pendidikan dan Kebudayaan. 2003. Kamus Besar Bahasa Indonesia. Jakarta: Balai Pustaka, h.943-944. yang berarti sifat religi yang melekat pada diri seseorang. ${ }^{15}$ Religius sebagai salah satu nilai karakter dideskripsikan oleh Suparlan sebagai sikap dan perilaku yang patuh dalam melaksanakan ajaran agama yang dianut, toleran terhadap pelaksanaan ibadah agama lain, dan hidup rukun dengan pemeluk agama lain. ${ }^{16}$

Berdasarkan pengertian konsep religius di atas, maka yang dimaksud dengan lingkungan sekolah yang religius adalah bahwa semua unsur sekolah yang meliputi guru, kepala sekolah, siswa serta tenaga nonkependidikan yang ada di sekolah, menunjukkan sikap dan perilaku yang didasari oleh nilai-nilai agama dan taat menjalankan ajaran agama dalam suasana hidup rukun dan toleran antara satu dengan yang lainnya.

\section{METODE PENELITIAN}

Jenis penelitian ini merupakan penelitian kualitatif deskriptif. Sesuai dengan jenis penelitian tersebut, maka metode pengumpulan data yang digunakan adalah dengan wawancara mendalam (indepth interview), Focus Group Discussion (FGD), dan observasi dan dokumentasi. Wawancara ditunjukkan kepada pimpinan lembaga/ sekolah, guru PAI (Pendidikan Agama Islam), komite sekolah, tim pengembangan kurikulum, dan beberapa siswa. Wawancara dimaksudkan untuk memperoleh data tentang: 1) Profil sasaran lembaga/seko-

${ }^{15}$ A. Thontowi. 2012. Hakkekat Religiusitas (Online), (http://www.sumsel.kemenag.gp.id, diakses tanggal 15 Maret 2015.

${ }^{16}$ Suparlan. 2010. Pendidikan karakter: Sedemikian pentingkah dan apa yang harus kita lakukan (online)' (http://www.suparlan.com), diakses 15 Maret 2015. 
lah; 2) Persepsi pimpinan, guru PAI dan siswa tentang PAI di sekolah; 3) Proses pembelajaran PAI sebagai upaya menciptakan lingkungan sekolah yang religius 4) Kendala yang dihadapi dalam pembelajaran PAI. FGD dengan beberapa kelompok siswa (1 kelompok antara 6-10 siswa) dan dilakukan berulang-ulang, dilakukan untuk mendiskusikan berbagai persoalan pembelajaran PAI. Observasi untuk mengamati objek penelitian khususnya yang berkaitan dengan proses pembelajaran PAI, serta sarana dan prasarana yang mendukung proses pembelajaran. Dokumentasi dimaksudkan untuk memperoleh data-data pendukung yang berupa dokumen-dokumen baik yang berupa: buku, silabus, RPP, CD, dan sebagainya.

Lokasi penelitian di Kota Bandung, sebagai ibu kota propinsi. Sedangkan sasaran penelitian adalah Sekolah Menengah Atas (SMA) Negeri 3 Bandung. Analisis data dilakukan mulai dari pengelompokan menjadi beberapa kategori, diolah dan direduksi serta disajikan secara deskriptif dalam bentuk tulisan naratif.

\section{HASIL DAN PEMBAHASAN}

\section{Seputar Perkembangan SMAN 3 Bandung}

Berdiri sejak tahun 1953 SMA Negeri 3 Bandung dikenal dengan sebutan SMA Belitung karena berlokasi di Jalan Belitung No. 8 Bandung. Sekolah ini merupakan sekolah favorit dan kebanggaan masyarakat kota Bandung. Lulusan dari sekolah ini banyak yang berhasil melanjutkan ke perguruan tinggi terkemuka di Indonesia terutama ITB, UI dan UNPAD, setiap tahunnya tidak kurang dari 60\%-80\% lulusan sekolah ini berhasil melanjutkan ke perguruan tinggi negeri.

Bangunan sekolah ini merupakan gedung tua yang dibangun pada zaman pemerintahan Hindia-Belanda (tahun 1916), dirancang oleh arsitekC.P Schoemaker. Yang berfungsi sebagai gedung HBS (Hoogere Burgerschool) yaitu sekolah untuk anakanak Belanda golongan menengah. Gedung ini berdiri di atas tanah seluas $14.240 \mathrm{~m} 2$ dengan luas bangunan $8.220 \mathrm{~m} 2$ menghadap ke utara (Jalan Belitung) dihuni oleh dua sekolah yaitu SMUN 3 Bandung di sebelah barat dan SMUN 5 Bandung di sebelah timur. Batas SMU 3 dan SMU 5 hanya dibatasi oleh jalur koridor tengah yang memanjang dari arah utara ke selatan. Batas koridor ini dapat juga berfungsi sebagai pemersatu antara SMA 3 dan SMA 5 sehingga para warga kedua sekolah ini dapat hidup berdampingan

\section{Visi dan Misi}

Sekolah yang mempunyai motto Knowledge is Power but Character is More, mencanangkan visinya sebagai berikut: "Menjadi sekolah berbasis riset terdepan dalam pembentukan karakter, berwawasan lingkungan unggul dalam Imtak dan Iptek." Untuk mencapai visi tersebut, maka misi yang dicanangkan adalah: 1) Membangun SDM yang unggul dalam Imtak dan Iptek sesuai dengan dinamika globalisasi, 2) Mewujudkan pendidik, tenaga kependidikan dan peserta didik yang memiliki integritas, 3) Mewujudkan lulusan yang berkarakter dan berwawasan kebangsaan, serta peduli terhadap lingkungan hidup, 4) Mengembangkan potensi kecerdasan intelektual, emosional dan spiritual guna memberikan solusi terhadap dina- 
mika permasalahan bangsa dan Negara, 5) Menjalin kemitraan dengan stakeholders (pemangku kepentingan) melalui peningkatan pelayanan prima, transparan dan akuntabel guna membangun komunikasi yang harmonis dengan mitra kerja secara formal dan nonformal.

\section{Tenaga Pendidik}

Sekolah yang pernah memperoleh prestasi sebagai sebagai Juara 1 Tingkat Nasional Kepala Sekolah berprestasi peduli pengembangan pendidikan agama Islam (PAI) tahun 2012, pada tahun pelajaran 2014/2015 memiliki tenaga pendidik (guru) sebanyak 69 (enam puluh sembilan) orang, terdiri dari: 33 laki-laki dan 36 perempuan. Guru Pendidikan Agama Islam (GPAI) terdapat 3 (tiga) orang, yaitu: 1) H. Dadang Suhaedar, M.Ag, 2) Hj. Nunung Nurhayari, M.Ag, dan 3) Hj. Diden Rosenda, M.Ag.

\section{Persepsi dan Kebijakan Pimpinan Terhadap PAI}

Keberhasilan proses pendidikan di sekolah melibatkan banyak unsur, seperti: pimpinan (Kepala Sekolah), guru (tenaga pendidik), pegawai administrasi (tenaga non kependidikan, anak didik, orang tua dan lainnya (seperti: pesuruh, satpam, cleaning service, dsb.). Tanpa adanya kerja sama yang baik antar semua unsur tersebut, proses pendidikan di sekolah tidak akan berjalan sesuai dengan harapan. Namun demikian, terciptanya sebuah kerja sama antar beberapa unsur pasti ada seorang pimpinan yang menjadi penggerak, penyemangat dan pendorong, tanpa ada pimpinan yang demikian kemungkinan sebuah proses apapun tidak akan berjalan dengan lancar.
Kondisi demikian nampak di SMA N 3 Kota Bandung. Wakil Kepala Sekolah Bidang Kurikulum SMA N 3 Bandung berpandangan bahwa:

"Sebagai pimpinan harus mengayomi semua unsur atau kelompok yang di sekolahnya, baik itu guru, tenaga administrasi, siswa bahkan pada pegawai honorer (seperti: satpam, pesuruh, cleaning sevice, dsb.). Begitu juga terhadap mata pelajaran, semua mata pelajaran adalah penting, baik itu mata pelajaran umum maupun pendidikan agama. Walaupun pendidikan agama Islam (PAI), tidak termasuk mata pelajaran kelompok Ujian Akhir Nasional (UAN), tetap mendapatkan perlakuan yang sama. Justru, PAI menjadi landasan bagi pembelajaran ilmu pengetahuan umum, mewarnai kehidupan di lingkungan SMA N 3 Bandung. Semua diperlakukan secara adil sesuai dengan tugas pokok dan fungsinya. Dengan demikian, diharapkan akan tercipta suasana yang harmonis dan nyaman sebagai syarat utama keberhasilan proses pendidikan. Di samping itu, apabila muncul benih-benih perpecahan ataupun perselisihan antar warga sekolah dapat segera diatasi". ${ }^{17}$

Selaras dengan pandangan tersebut, maka untuk mewujudkan suasana sekolah yang harmonis dan nyaman adalah dengan memaksimalkan pendidikan agama Islam (PAI). Hal ini dimaksudkan, terciptanya lingkungan sekolah tidak hanya harmonis dan nyaman, tetapi lingkungan sekolah yang harmonis dan nyaman yang dibingkai dengan nilai-nilai agama.

Lebih lanjut, Bapak Zainal Asikin berpandangan bahwa dalam pembentukan karakter yang Islami seorang pimpinan

${ }^{17}$ Hasil Wawancara dengan Zainal Asikin, Wakil Kepala Sekolah SMAN 3 Bandung, 14 - 15 Oktober 2014 
harus memiliki sifat-sifat sebagai berikut: Pertama, Leader; sebagai seorang pimpinan harus bisa menjadi contoh teladan, tidak hanya sebatas pada tugas memerintahkan kepada anak buahnya.

Kedua, Menghargai anak didik; siswa sebagai anak didik bukan berarti anak yang bisa diperintah oleh siapa saja dan disuruh mengerjakan tugas. Tetapi lebih dari itu, anak adalah sahabat. Jadi antara satu dengan yang lain, baik antara siswa dengan pimpinan, siswa dengan guru, keduanya bisa saling berbagi. Pimpinan maupun guru bukanlah segalanya, sebaliknya sebagai seorang yang lebih senior selayaknya memahami dan menghargai potensi yang dimiliki oleh anak, baik kelebihan maupun kekurangannya. Kadang, pimpinan maupun guru juga bisa belajar dari anak. Di samping itu, dengan memperlakukan anak sebagai sahabat, maka anak bisa dengan terbuka menyampaikan sesuatu kepada gurunya tanpa adanya rasa bersalah ataupun takut. Dengan kondisi demikian, maka akan tercipta komunikasi yang timbal balik dan suasana yang terbuka dan nyaman. Yang pada akhirnya, anak akan merasa senang belajar dan berada di lingkungan sekolah layaknya di rumahnya sendiri.

Ketiga, pendekatan yang diterapkan dalam memimpin sekolahnya adalah dengan "Pendekatan cultural" bukan pendekatan struktural. Budaya yang sudah melekat di berbagai unsur dan sistem "diperhalus". Selanjutnya, dalam pemberian sesuatu bagi para murid ataupun guru apabila melakukan sesuatu hal, bukan dalam bentuk sangsi "punishment" tetapi "reward" atau penghargaan. Dengan demikian, semua orang tidak ada yang merasa direndahkan, dipermalukan ataupun diberi hukuman.
Karena yang dimunculkan adalah kebaikannya bukan kejelekannya ataupun kesalahannya.

Keempat, menghargai potensi para guru; dengan menganjurkan kepada para guru untuk berbagi dalam bekerja. Artinya, potensi yang dimiliki oleh para guru benar-benar harus dihargai. Misal, dengan memberikan kesempatan kepada para guru untuk mengembangkan potensinya tidak hanya di dalam lingkungan sekolah, tetapi di luar sekolah. Para senior selalu diajak untuk bermusyawarah dalam setiap pembuatan kebijakan sekolah.

Sebagaimana konsep indikator yang dibuat oleh pemerintah (Kemendikbud), bahwa indikator pertama tentang karakter adalah religiusitas. Oleh karena itu, penanaman religiusitas pada anak harus menjadi prioritas utama. Di SMA N 3 Bandung, salah satu bentuk pembentukan anak yang berkarakter Islami dan tercipta suasana sekolah yang religius adalah yang disebut MT-PAI, yakni kegiatan ekstrakurikuler yang terintegrasi dengan mata pelajaran PAI.

\section{Persepsi Siswa Tentang PAI}

Hampir semua siswa yang terlibat dalam FGD tentang PAI berpendapat, bahwa mata pelajaran PAI menarik, baik untuk dipelajari, dipahami maupun diamalkan dalam kehidupan sehari-hari. Oleh karena itu, mereka cukup antusias mengikuti pembelajaran PAI, di samping karena faktor kewajiban harus mengikutinya sesuai dengan kurikulum. Namun demikian, ada beberapa hal yang dianggap sulit untuk dipelajari, seperti: ketika materi hafalan ayat-ayat al-Qur'an yang cukup panjang 
yang kadang menyita waktu belajar. Ada yang berpendapat juga materi Fikih juga agak sulit untuk dipelajari.

Di samping itu, dukungan dan kerja sama dari beberapa pihak (kepala sekolah dan guru mata pelajaran non PAI) memberikan motivasi/dorongan yang positif bagi siswa untuk mengikuti dengan sungguh-sungguh mata pelajaran PAI. Bentuk dukungan yang diberikan pimpinan adalah: penyediaan sarana dan fasilitas beribadah yang memadai (masjid/mushola), kebijakan yang tidak membeda-bedakan antara mata pelajaran satu dengan lainnya, dan penyediaan sarana laboratorium PAI. Dalam beberapa kesempatan, pimpinan sekolah juga sering menekankan pentingnya beragama.

Dukungan lain dari guru adalah pemberian kesempatan kepada murid untuk segera melaksanakan sholat ketika azan sudah berkumandang, dan doa sebelum pembelajaran dimulai yang dilanjutkan dengan tadarus (pembacaan beberapa ayatayat al Qur'an). Keaktifan pimpinan dan guru untuk sholat berjamaah, aktif dalam kepanitiaan kegiatan hari-hari besar Islam dan kegiatan ekstrakurikuler keagamaan lainnya (seperti Senam Kesegaran Jasmani di SMK 6) selalu diawali dengan pembacaan ayat-ayat al-Qur'an, juga merupakan bentuk dukungan yang positif terhadap pembelajaran PAI.

Dalam aplikasi sehari-hari yang sangat dibutuhkan oleh siswa adalah pimpinan sekolah dan guru baik itu guru PAI itu sendiri maupun guru mata pelajaran lain sebagai "modelling", contoh teladan nyata dalam kehidupan sehari-hari. Kalau pimpinan sekolah dan guru tidak menampilkan diri sebagai sosok yang dapat ditiru/dicontoh, maka siapa lagi yang akan menjadi panutan dan suri teladan di sekolah.

Namun demikian, ada keluhan dari beberapa siswa dan juga dari pengamatan langsung, ketika proses pembelajaran PAI terkadang ada beberapa siswa yang tidak dengan sungguh-sungguh mendengarkan guru ketika sedang menjelaskan materi. Misalnya masih adanya siswa yang bercanda, saling mengobrol, dan bermain handphone (HP), kondisi ini cukup mengganggu siswa lain.

\section{Strategi Pendidikan Agama Islam dalam Mewujudkan Lingkungan Sekolah yang Religius}

\section{Mentoring Terintegrasi PAI (MT-PAI)}

Dalam buku panduan MT-PAI ${ }^{18}$, dijelaskan bahwa dengan diberlakukannya berbagai undang-undang, baik secara langsung maupun tidak langsung yang berkaitan dengan pendidikan, seperti UU Nomor 22 Tahun 1999 Tentang Pemerintah daerah dan Peraturan Pemerintah No. 25 Tahun 2000 tentang Kewenangan Pemerintah dan Kewenangan Propinsi Sebagai Daerah Otonom, UU No. 20 Tahun 2003 tentang Sistem Pendidikan Nasional, maka SMA Negeri 3 Bandung sebagai salah satu lembaga pendidikan formal senantiasa merespons secara cepat dan tepat, dalam rangka meningkatkan peran dan fungsinya yang terlibat langsung dalam pelaksanaan pendidikan dan pembelajaran. Hal ini dapat dilakukan melalui berbagai pembinaan, salah satunya pembinaan akhlak mulia dalam meningkatkan keimanan dan

${ }^{18}$ Buku Panduan Kegiatan MT-PAI, SMA Negeri 3 Bandung 2014. h. 1. 
ketakwaan terhadap Allah SWT melalui peningkatan kualitas Pendidikan Agama Islam secara efektif dan efisien. Landasan ideal penyelenggaraan PAI adalah Al Qur'an Surat: Al-Mujadalah: 11 yang artinya:

"Wahai orang-orang yang beriman, apabila dikatakan kepadamu: berilah kelapangan dalam majelis-majelis, maka lapangkanlah, niscaya Allah akan memberi kelapangan untukmu. dan apabila dikatakan, berdirilah kamu, maka berdirilah, niscaya Allah mengangkat (derajat) orang-orang yang beriman di antaramu dan orang-orang yang diberi ilmu beberapa derajat, dan Allah Maha teliti apa yang kamu kerjakan". ${ }^{19}$

Sedangkan landasan konstitusional penyelenggaraan PAI adalah Undang-undang Dasar tahun 1945 (Pasal 28C, 28E dan Pasal 31) dan Undang-undang RI No. 20 /2003 tentang Sistem Pendidikan Nasional. Landasan operasionalnya adalah program kerja sekolah tentang peningkatan IMTAK.20

Visi penyelenggaraan PAI adalah "terwujudnya sekolah bernuansa religius, berdaya saing tinggi, menuju sekolah efektif, berbasis teknologi informasi dan komunikasi". Untuk mencapai visi tersebut, maka misi yang dikembangkan adalah 1) Meningkatkan keimanan dan ketakwaan terhadap Allah SWT, 2) Meningkatkan proses pembelajaran, 3) Meningkatkan kualitas dan kuantitas lulusan yang diterima di perguruan tinggi terbaik, 4) Membangun sikap disiplin, etos kerja, kepercayaan diri dan kebersamaan, 5) Meningkatkan prestasi kerja yang dilandasi komitmen dan sikap profesionalisme, 6) Membangun

19 Departemen Agama, 2005. Al Qur'an dan Terjemahnya. P. 792

${ }^{20}$ Buku Panduan MT-PAI, Op.Cit. h. 2 kemandirian inovatif, kondusif dan akuntabel, 7) Memberi pelayan prima kepada stakeholders, dan 8) Meningkatkan kualitas dan kuantitas sarana dan prasarana teknologi informasi dan komunikasi. ${ }^{21}$

Tujuan PAI di SMA adalah: 1) Menumbuhkembangkan akidah melalui pemberian, pemupukan, dan pengembangan pengetahuan, penghayatan, pengamalan, pembiasaan, serta pengalaman peserta didik tentang Agama Islam sehingga menjadi manusia muslim yang terus berkembang keimanan dan ketakwaannya kepada Allah SWT, 2) Mewujudkan manusia Indonesia yang taat beragama dan berakhlak mulia yaitu manusia yang berpengetahuan, rajin beribadah, cerdas, produktif, jujur, adil, etis, berdisiplin, bertoleransi (tasamuh), menjaga keharmonisan secara personal dan sosial serta mengembangkan budaya agama dalam komunitas sekolah. ${ }^{22}$

\section{Strategi Pembelajaran PAI}

Strategi pembelajaran PAI dilakukan melalui 3 (tiga) aspek, yang meliputi: Pertama, Strategi Pembinaan Keimanan dan Ketakwaan terhadap Tuhan Yang Maha Esa, melalui: mata pelajaran PAI, integrasi dengan mata pelajaran lain, kegiatan Ekstrakulikuler PAI, penciptaan situasi yang kondusif dan Islami, dan kerja sama dengan masyarakat atau dengan tokoh masyarakat.

Kedua, Strategi pembinaan ibadah; peningkatan pelaksanaan: ibadah mahdhah melalui pembiasaan shalat wajib tepat waktu dan berjamaah, tadarus Al-Qur'an, shalat sunat melaluipembiasaan shalat dluha ketika

\footnotetext{
${ }^{21}$ Ibid.., h. 2.

${ }^{22}$ Buku Panduan MT-PAI, Op.Cit. h. 5
} 
istirahat, doa melalui pembiasaan berdoa awal dan akhir pelajaran dan mendoakan warga SMA Negeri 3 yang sakit, meninggal dunia dan yang kena musibah, dan ibadah muamalah diwujudkan melalui pembiasaan menyantuni kepada yang tertimpa musibah, bakti sosial ke Panti (Jompo, Yatim/piatu dan bayi sehat) dan kepada warga SMA Negeri 3 Bandung yang membutuhkan.

Ketiga, Strategi Pembinaan Akhlak Mulia; peningkatan akhlak mulia: a) terhadap Allah SWT melalui pembiasaan dalam penerapan/ melaksanakan ibadah mahdhah yang ikhlas, ridha dan tawakal kepada Allah SWT, b) terhadap diri sendiri melalui pembiasaan sabar dalam menjauhkan diri segala perilaku yang dilarang oleh Allah SWT, c) terhadap sesama diterapkan melalui pembiasaan, saling menghormati, saling menghargai serta tolong menolong yang didasari niat karena Allah SWT, dan d) akhlak terhadap lingkungan, diterapkan melalui pembiasaan menjaga dan melestarikan lingkungan hidup di lingkungan sekolah dan sekitarnya.

Kegiatan MT-PAI didesain melalui berbagai macam²3, yaitu: (1) Kegiatan Harian; meliputi tadarus al Qur'an di awal jam pelajaran, berdo'a awal dan akhir pelajaran, Ta'liman pagi, mengumandangkan Asmaul Husna, Shalat Dluha (ibu/bapak guru/TU/ siswa/siswa, mengumandangkan adzan dhuhur dan shalat Dhuhur berjamaah; (2) Kegiatan Mingguan; meliputi: shalat Jum'at bersama/bagi laki-laki (guru, TU, siswa), BTQ (Belajar Baca Tulis al-Qur'an), Mentoring PAI, menggunakan busana Muslim tiap hari jum'at/guru, TU dan siswa), keputrian mesjid, dan shadaqah/infak tiap hari Jum'at;

(3) Kegiatan Bulanan; diskusi Islami putra/

\footnotetext{
${ }^{23}$ Buku Panduan MT-PAI, Op.Cit. h. 6
}

putri, pengajian rutin (ibu/bapak guru dan TU) awal bulan/tanggal 1, dan Rihlah/ tadabur alam; (4) Kegiatan Semesteran; Mabit DKM putra/putri, Rihlah DKM Putra/ putri/daurah putra-putri, Debat Islami di sekolah dan lenbaga lain, serta mengirimkan siswa/siswi mengikuti kegiatan keagamaan di sekolah/lembaga lain; (5) Kegiatan Tahunan; meliputi: Ta'aruf awal tahun pelajaran (kelas X), PHBI (peringatan hari besar Islam), pesantren Ramadhan, bakti sosial, halal bi halal (ibu/bapak guru/TU/ Purna bakti), penyembelihan hewan Qurban (bulan Haji), peragaan manasik Haji (Kelas XII), doa bersama (Untuk kelas XII), dan Mabit /Tahajud bersama (Kelas XII).

Selain kegiatan-kegiatan tersebut di atas yang sifatnya rutin (harian, mingguan, bulanan, semesteran maupun tahunan), diselenggarakan juga kegiatan yang sifatnya temporer/insidentil, tetapi terintegrasi dengan mata pelajaran PAI. Di antaranya adalah "3ID (Three Islamic Day) for Bandung Agamis 2010", tempat di SMAN 3 Bandung dengan peserta adalah siswa-siswi SD dan SMP/MTs Negeri maupun swasta se Kota Bandung. Kegiatan ini diselenggarakan oleh OSIS LVIII SMA N 3 Bandung dan dilaksanakan di luar jam pelajaran, yaitu di hari Minggu (3 Oktober 2010, dari jam 08.00 -16.00).

Kegiatan yang berkonsep lomba dan bazar Islami ini dimaksudkan untuk terus menjaga serta meningkatkan semangat mencintai Al-Qur'an dan mempelajari ilmuagama sejak usia muda. Hal ini sejalan dengan moto SMAN 3 Bandung yang mengandung makna pembangunan karakter dan pengetahuan. Jenis kegiatan yang diperlombakan terdiri dari: Tilawah Qur'an, Hafalan Qur'an, Cerdas Cermat Islam, Kaligrafi, Nasyid dan Dakwah. 
Sedangkan Bazaar Islami diisi dengan Stand Buku/Referensi Islami dan stand para sponsor kegiatan.

Dari beberapa kegiatan keagamaan yang diselenggarakan di SMA N 3 Bandung tersebut, yang pelaksanaannya terintegrasi dengan mata pelajaran PAI adalah mentoring. Selanjutnya kegiatan ini disebut dengan Mentoring Terintegrasi PAI (MTPAI). Secara rinci tentang kegiatan MT-PAI dapat dijelaskan di bawah.

\section{Strategi melalui MT-PAI}

Kegiatan mentoring diawali pada tahun 2002 dengan nama Forum Studi Islam Intensif. Program ini bertujuan untuk membekali siswa SMA N 3 Bandung untuk memahami ajaran Islam yang lurus dan utuh. Pada tahun 2008 namanya berubah lagi menjadi Explosive (Explore Islam Intensive) dengan tujuan yang sama, namun lebih menitikberatkan kepada syiar nilainilai keislaman praktis. Sampai tahun 2012 kepengurusan Explosive masih dipegang oleh DKM Al Furqan SMA N 3 Bandung.

Setelah dilakukan evaluasi, kegiatan mentoring yang 2 (dua) kali mengalami pergantian nama, maka pada tahun 2013 diintegrasikan dengan mata pelajaran PAI dengan nama Program Mentoring Terintegrasi PAI (MT-PAI). Format pengelolaannya adalah mengintegrasikan antara materi PAI di kelas dengan materi mentoring, dengan pengelola oleh sekolah yang dibantu siswa yang ditunjuk langsung oleh guru PAI.

Pembentukan MT-PAI dilandasi oleh landasan ideal, institusional dan landasan operasional. Landasan ideal yang dipakai adalah ayat-ayat al Qur'an (QS Al Mujadalah: 11; QS az Zumar: 9; QS Thaaha: 134; QS al Baqarah: 269; dan QS al Ankabut: 43), dan beberapa Hadits tertentu. Landasan institusional adalah: Undang-undang No. 20 Tahun 2003, PP No.55 Tahun 2007 tentang Pendidikan Agama dan Pendidikan Keagamaan, Keputusan Bersama Menteri Pendidikan dan Kebudayaan dengan Menteri Agama No. 4/U/SKB/1999 tentang Pelaksanaan Pembinaan Pendidikan Agama padaSatuan Pendidikan Dasar dan menengah di Lingkungan Pembinaan Direktorat Jenderal Pendidikan dasar dan menengah Departemen Pendidikan dan Kebudayaan, dan Peraturan Menteri Pendidikan Nasional No. 39/2008 tentang Pembinaan kesiswaan. Sedangkan landasan operasionalnya adalah: Visi, Misi dan Motto SMA N 3 Bandung. ${ }^{24}$

Tujuan umum dari kegiatan MTPAI adalah "Membentuk sumber daya manusia yang berakhlakul-karimah sebagai manifestasi dari upaya peningkatan ketakwaan terhadap Tuhan Yang Maha Esa. Sedangkan tujuan khususnya adalah: 1) Mengembangkan intelektual siswa dalam mata pelajaran PAI, 2) Menjalin ukhuwah antarsiswa

SMA N 3 Bandung, 3) Terbinanya kehidupan beragama di lingkungan SMA N 3 Bandung, 4) Meningkatkan kualitas dan kreativitas siswa SMA N 3 Bandung, 5) Meningkatkan kecintaan siswa SMA N 3 Bandung terhadap masjid, dan 6) Mengondisikan siswa dalam menyebarluaskan syiar Islam di lingkungan SMA N 3 Bandung.

Waktu pelaksanaan program MT-PAI SMA N 3 Bandung pada semester 1 (ganjil) setiap hari Jum'at pukul 13.00 - 15.00, bertempat di masjid SMA N 3 Bandung, aula di

${ }^{24}$ Buku Panduan MT-PAI, Op.Cit. h. 8 
Laboratorium PAI dan luar sekolah (misal di alam terbuka). Bentuk kegiatannya adalah metode mentoring dengan jumlah siswa 8 - 10 orang, yang disesuaikan dengan karakter anak yang masih termasuk dalam usia pencarian identitas. Materi mentoring disesuaikan dengan silabus PAI pada semester 1, yang mencakup: tema al Qur'an (tahsin, hafalan ayat-ayat al Qur'an dan akhlak), Asmaul Husna, Akhlaq terpuji, hukum Islam dan keteladanan Rasulullah SAW.

Peserta MT-PAI adalah semua siswa yang beragama Islam, yang mengambil/ mengontrak mata pelajaran PAI semester 1 (PAI 1). Oleh karena itu, siswa berkewajiban untuk: a) Mengikuti kegiatan mentoring dengan ikhlas dan sepenuh hati, b) Memelihara kebersihan, keindahan, ketertiban dan keamanan seluruh sarana dan prasarana, Lab. PAI dan masjid sekolah serta lingkungannya, dan c) Menaati dan mematuhi segala ketentuan dan peraturan yang berlaku di program MT-PAI. Di samping adanya kewajiban yang harus diikuti oleh siswa, ada hak yang diperoleh oleh siswa, yaitu: a) Memperoleh layanan bimbingan pembelajaran untuk mendukung penyelesaian MT-PAI, b) Memperoleh sertifikat setelah dinyatakan lulus.

Sesuai dengan misi MT-PAI adalah untuk membentuk siswa yang berakhlaqul karimah di dalam dan di luar kelas, jika siswa tidak lulus dalam program mentoring ini maka siswa bersangkutan dinyatakan tidak lulus dalam mata pelajaran PAI. Hal itu didasari bahwa pelajaran PAI yang telah diajarkan di kelas dapat terus diaplikasikan oleh siswa kapan saja, sehingga hal tersebut akan menjadi ciri khas siswa SMA N 3 Bandung yang tidak hanya unggul dalam bidang akademis, namun juga berkepribadian yang kuat dan akhlak yang luhur.

Pengelola: Sesuai dengan bentuk mentoring yang terintegrasi dengan mata pelajaran PAI, maka sebagai pembina adalah seluruh guru PAI SMA N 3 Bandung bekerja sama dengan Ikatan Keluarga Alumni SMA N 3 Bandung. Adapun tugas pembina adalah: a. Memberikan bimbingan dan penyelenggaraan kegiatan mentoring sesuai dengan tugas yang diberikan kepada pengurus harian, b. Mewajibkan seluruh siswa di kelas yang dipegangnya untuk mengikuti program MT-PAI. Sedangkan sebagai pengurus harian adalah siswa kelas XI yang telah dinyatakan lulus mata pelajaran PAI semester 1 (PAI 1) dengan kualifikasi baik. Sebagai mentornya adalah korps mentor IKA SMA N 3 Bandung atau siswa yang telah ditunjuk oleh guru PAI SMA N 3 Bandung yang mempunyai keterampilan membina dan berkomitmen terhadap MTPAI.

Metode Program MT-PAI: Kuliah umum; adalah kajian keislaman kontemporer yang dilakukan secara umum dalam masjid sekolah. Semua siswa berkumpul di dalam masjid untuk mengikuti kuliah general, yang bertujuan: 1) Sebagai sarana silaturahim seluruh siswa muslim pengontrak PAI atau peserta program MT-PAI SMA N 3 Bandung, baik itu dengan sesama mereka maupun dengan kakak kelasnya, pengelola mentoring, serta guru PAI dan guru SMA N 3 Bandung lainnya; 2) proses internalisasi dan pembiasaan siswa untuk senantiasa terbiasa beri'tikaf di dalam masjid; 3) Memakmurkan masjid SMA N 3 Bandung; 4) Proses ta'lim muta'alim yang refreshing, sehingga kesan pengajian yang monoton tidak berlaku untuk kegiatan ini; dan 5) Sarana eksplorasi nilai- 
nilai Islam ke dalam kehidupan siswa SMA N 3 Bandung. Adapun bentuk acara kuliah general adalah: 1) Talkshow atau diskusi panel; 2) Kajian tematik; 3) Bedah buku; 4) Ceramah umum; 5) Tahsin al Qur'an; dan 6) Training/simulasi aplikatif.

Mentoring; merupakan sebuah model pembinaan yang dilakukan dalam sebuah kelompok kecil, yang dapat digunakan sebagai sarana mengkaji nilai-nilai agama Islam yang dikemas dalam bentuk kegiatan aplikatif-kreatif. Mentoring dipandu dan dibimbing oleh seorang mentor, di mana mentor tersebut merupakan senior sehingga proses bimbingan yang dilakukan akan lebih terarah dantepat sasaran. Saatini, mentoring keislaman seperti yang dilakukan (walau dengan format yang berbeda) sudah tersebar secara luas baik di sekolah-sekolah maupun di perguruan tinggi. Hal ini disebabkan mentoring merupakan bentuk pembinaan yang memiliki keunggulan, di antaranya: 1) Mentoring (halaqah) merupakan sunnah yang dilakukan oleh Rasulullah SAW dalam membina dan mengembangkan pemahaman keislaman kepada para sahabat. Cara ini terbukti efektif sebagai stabilitas pembinaan keimanan dan ketakwaan pada masa tersebut dan masa kini; 2) Pemantauan terhadap perkembangan kualitas siswa dapat dilakukan secara lebih intensif dan melekat dari seorang mentor; 3) Pembinaan yang dilakukan bersifat kontinu sehingga memungkinkan untuk melakukan evaluasi secara lebih aktual; dan 4) Mentoring yang dilakukan dengan baik akan menciptakan ukhuwah yang terjalin dalam suatu kelompok tersebut, lebih signifikan dari pada bentuk pembinaan yang lain. Karena pada tahapan ini, kontinuitas pertemuan menjadi syarat mutlak pelaksanaan mentoring. Antara sesama individu yang tergabung dalam kelompok dapat terjalin hubungan yang harmonis.

Outbound; yaitu kegiatan dengan beragam simulasi yang dilakukan di ruang atau di alam terbuka untuk melatih kemandirian siswa tanpa mengesampingkan nilai-nilai keislaman di dalamnya, agar tujuan dari mentoring itu sendiri tidak hilang begitu saja. Agar lebih menarik dan variatif, kegiatan ini diformat dalam sebuah perjalanan ringan, menempatkan permainan dan simulasi-simulasi aplikatif pada setiap pos/tahapan yang dilalui. Beberapa manfaat yang dapat diperoleh dari kegiatan ini antara lain: 1) Meningkatkan ukhuwah antara pengurus mentoring, mentor dan siswa; 2) Memberikan efek ketertarikan dn refreshing sehingga dapat menghilangkan kejenuhan selama kegiatan mentoring yang bersifat klasik dan rutin; 3) Meningkatkan kualitas jasdiyah, karena pembinaan yang dilakukan benar-benar mengandalkan jasad atau fisik peserta, dan 4) Mengintegrasikan 3 (tiga) aspek pendidikan dan pembinaan (kognitif, afektif dan psikomotorik).

Bakti sosial; bakti sosial yang dapat dilakukan oleh peserta MT-PAI adalah dengan menjadi kakak asuh pada program adik asuh dengan menyisihkan uang saku setiap pekan sebagai sedekah bagi adik asuh dalam menempuh pendidikan formal mereka. Selain itu, siswa juga dapat mewakafkan buku-buku Islam kepada perpustakaan sekolah atau laboratorium PAI. Tentu saja beban siswa tidak terlalu besar karena mereka melakukan itu secara kolektif. Dengan kedua kegiatan bakti sosial ini, siswa telah secara langsung berkontribusi terhadap sosial, pendidikan dan pengamalan nilai-nilai Islami. 
Pembiayaan: Dana untuk kegiatan MTPAI bersumber dari APBS Rp. 50.000,-/siswa. Di samping juga Memberikan kesempatan kepada pihak lain (spt. Pejabat pemerintah, pimpinan perusahaan, instansi atau perorangan berupa sponsorship atau donasi.

Silabus Aplikatif: Setelah mengikuti MTPAI, peserta diharapkan memiliki karakter sebagai berikut:

a. Perangai Islami

1) Menampilkan perilaku sebagai khalifah di bumi (QS al-Baqarah: 30; al Mukminun: 12-14; az Zariyat: 56 dan an Nahl: 78). Misal dengan selalu menjaga kebersihan lingkungan, yaitu membuang sampah pada tempatnya dan selalu bersyukur.

2) Akhlak Rasulullah; bertujuan agar peserta dapat meneladani akhlak Rasulullah, dengan metode yang digunakan adalah menyampaikan kisah inspiratif (mis: Aku hanyalah seorang hamba"), dan simulasi dengan menebak karakter teman sekelompok. Sebagai alat pendukung adalah kertas HVS A6 sejumlah peserta.

3) Birul walidain (berbakti kepada orang tua); bertujuan agar peserta (siswa) memahami kewajiban kepada orang tua. Metode yang dipakai adalah menonton video kisah pohon apel.

b. Kesadaran melaksanakan ibadah wajib

1) Menampilkan perilaku ikhlas dalam beribadah (QS al An'am: 162-163 dan al Bayyinah: 5). Metode yang digunakan adalah training shalat khusyuk.

2) Ikhlas, yang bertujuan agar siswa berusaha ikhlas dalam ibadah dan menjalani kehidupan. Metode yang digunakan adalah menampilkan kisah- kisah inspiratif, seperti: kisah gara-gara tidak ikhlas dan kisah kalung mutiara. Di samping itu juga diadakan diskusi, agar siswa dapat memahami secara baik.

c. Dapat membaca al Qur'an dengan baik; training singkat cara mudah menerjemahkan ayat al Qur'an

d. Semangat belajar Islam; bertujuan agar siswa memiliki semangat tinggi untuk belajar tentang islam. Metode yang digunakan adalah menampilkan kisah inspiratif dan simulasi.

e. Semangat memperbaiki diri; bertujuan agar siswa memiliki tekad yang kuat untuk selalu memperbaiki diri. Metode yang digunakan adalah menampilkan kisah inspiratif melalui tayangan video yang berisi motivasi untuk meraih mimpi. Di samping itu juga diadakan simulasi dengan menulis 10 (sepuluh) mimpi dan 10 (sepuluh) perbaikan diri. Alat yang digunakan adalah kertas HVS sejumlah peserta.

f. Menjauhi organisasi yang memusuhi Islam; bertujuan agar siswa mengetahui organisasi-organisasi yang memusuhi Islam, dengan menampilkan kisah inspiratif ("Rahasia kecerdasan kaum yahudi"). Dilengkapi juga dengan simulasi yang berupa permainan/game antara warga, polisi dan penjahat.

\section{Target Kegiatan}

Setelah mengikuti kegiatan MT-OAI, diharapkan seluruh masyarakat SMA Negeri 3 Bandung mampu meningkatkan keimanan dan ketakwaan terhadap Allah SWT serta bersikap dan berperilaku akhlaqul karimah. Di samping itu, dapat terwujud lingkungan 
sekolah yang asri/lestari, kondusif dan Islami.

Sebagaimana diungkapkan para ahli pendidikan, bahwa budaya religius sekolah adalah cara berpikir dan cara bertindak warga sekolah yang didasarkan atas nilainilai religius (keberagamaan). Religius menurut Islam adalah menjalankan ajaran agama secara menyeluruh (kaffah).

Tradisi dan perwujudan ajaran agama memiliki keterkaitan yang erat, karena itu tradisi tidak dapat dipisahkan begitu saja dari masyarakat/lembaga di mana ia dipertahankan, sedangkan masyarakat juga mempunyai hubungan timbal balik, bahkan saling mempengaruhi dengan agama. Menurut Mukti Ali, agama mempengaruhi jalannya masyarakat dan pertumbuhan masyarakat mempengaruhi pemikiran terhadap agama. Dalam kaitan ini, Sudjatmoko juga menyatakan bahwa keberagamaan manusia, pada saat yang bersamaan selalu disertai dengan identitas budayanya masing-masing yang berbedabeda. ${ }^{25}$

Oleh karena itu, untuk membudayakan nilai-nilai keberagamaan (religius) dapat dilakukan dengan beberapa cara, antara lain melalui: kebijakan pimpinan sekolah, pelaksanaan kegiatan belajar mengajar di kelas, kegiatan ektrakurikuler di luar kelas serta tradisi dan perilaku warga sekolah secara kontinu dan konsisten, sehingga tercipta religious culture tersebut dalam lingkungan sekolah.

${ }^{25}$ Mukti Ali dan Sudjatmoko sebagaimana dikutip Asrori dalam http://kabar-pendidikan.blogspot. com/2011/04/budaya-religius-sekolah.html, diakses tanggal 21 November 2014).
Di SMA N 3 Bandung, kebijakan pimpinan memegang peranan penting dalam penciptaan lingkungan sekolah yang religius, sebagai upaya membudayakan nilainilai keagamaan. Kebijakan tersebut didasari pada pemikiran bahwa dengan menciptakan lingkungan yang religius, maka pemikiranpemikiran ataupun tindakan-tindakan yang mengarah para perselisihan antar individu, antar unsur di sekolah baik secara horizontal maupun vertikal dapat diminimalisir.

Wujud keberpihakan pimpinan sekolah dalam menciptakan sekolah sebagai lingkungan yang religius adanya kebijakan dengan menerapkan/memberlakukan program Mentoring Terintegrasi PAI (MTPAI) di SMA N 3 Bandung. MT-PAI sebagai suatu kegiatan ekstrakurikuler keagamaan menjadi bagian tak terpisahkan dengan pembelajaran PAI secara utuh. Kegiatan MT-PAI yang terdiri dari berbagai macam kegiatan dan metode yang bervariasi, merupakan kegiatan pengayaan dan media pendalaman materi yang diperoleh di kelas. Mulai dari silabus yang mengacu pada kurikulum PAI sampai pada penilaiannya bagaikan dua sisi mata uang yang tidak bisa dipisahkan, saling mengisi dan melengkapi. Bagi siswa yang belum memperoleh tanda lulus dari program MT-PAI maka siswa belum bisa dinyatakan lulus mata pelajaran PAI. Oleh karena itu, semua siswa yang beragama Islam wajib mengikuti program MT-PAI.

Dengan banyaknya kegiatan keagamaan yang bertujuan untuk mengasah dan meningkatkan kualitas keberagamaan siswa, maka dengan sendirinya tidak akan ada waktu bagi siswa untuk berpikir dan berperilaku negatif yang mengarah pada perselisihan ataupun pertentangan, baik 
antara siswa, maupun siswa dengan guru. Di samping itu, dengan adanya pendalaman materi PAI, maka materi pelajaran PAI dapat diaplikasikan dalam kehidupan sehari-hari. Seperti:akhlak/perangaiterhadap orangtua, terhadap guru, pimpinan dan juga sesama siswa/teman. Dengan demikian, benih-benih perselisihan ataupun pertentangan yang mengarah pada konflik ataupun kekerasan jarang terjadi. Kalaupun ada, karena gedung SMA N 3 dan SMA N 5 Bandung menyatu dan dibatasi sebuah koridor yang bisa dilalui oleh siapa saja, justru bersifat positif (karena adanya kompetitif) untuk berprestasi yang lebih baik.

Dalam tataran pengamalan kehidupan sehari-hari, nilai-nilai atau aspek-aspek religiusitas seperti semangat berkorban (jihad), semangat persaudaraan (ukhuwah), semangat saling menolong (ta'awun) dan aspek religiusitas mulia lainnya selalu mewarnai dalam sikap dari semua unsur sekolah (siswa, pimpinan dan guru). Begitu juga dalam tataran perilaku, pembiasaan pelaksanaan kewajiban agama yang berupa: sholat berjamaah, gemar bersedekah, rajin belajar dan perilaku yang mulia selalu tercermin pada perilaku siswa, guru, pimpinan dan lainnya (tenaga non kependidikan) dalam kehidupan sehari-hari di sekolah.

Dengan demikian, budaya religius sebagai terwujudnya nilai-nilai ajaran agama dalam berperilaku dan berbudaya semua warga sekolah, benar-benar menjadi satu pengendali dan benteng bagi semua warga sekolah untuk bersikap dan berperilaku negatif, seperti konflik dan kekerasan antar warga di sekolah. Sehingga tidak akan ada waktu ataupun keinginan, pemikiran negatif yang ada dalam diri warga sekolah. Yang ada adalah belajar dan berprestasi.

\section{PENUTUP}

\section{Kesimpulan}

Persepsi pimpinan (kepala sekolah) terhadap PAI sangat positif, yang diwujudkan dalam bentuk kebijakan terhadap penyelenggaraan pembelajaran PAI dalam kegiatan intrakurikuler maupun ekstrakurikuler. Bentuk kebijakan yang diterapkan adalah dengan memaksimalkan pembelajaran PAI yang diharapkan dapat tercipta lingkungan sekolah yang religius. Artinya, sikap dan perilaku semua warga sekolah (pimpinan, guru, siswa dan tenaga nonkependidikan lainnya) selalu dilandasi oleh nilai-nilai agama. Dengan demikian, maka benih-benih sikap dan perilaku negatif yang dapat mengganggu proses dan keberhasilan pendidikan dapat dicegah dan diminimalisir sedini mungkin. Salah satu strategi pembelajaran PAI yang diterapkan adalah dengan mengintegrasikan antara kegiatan ekstrakurikuler (mentoring) dengan mata pelajaran PAI yang disebut dengan MT-PAI (Mentoring Terintegrasi Pendidikan Agama Islam) di SMA N 3 Bandung.

Sementara persepsi menurut siswa, bahwa PAI cukup menarik dan mudah untuk dipelajari, dan materinya mudah diamalkan/ dipraktikkan dalam kehidupan sehari-hari. Hanya ada beberapa hal yang dianggap sulit, misal materi hafalan ayat yang panjang. Strategi pembelajaran untuk menciptakan lingkungan sekolah yang religius adalah sebagai wujud peran pendidikan agama Islam (PAI) adalah dengan memaksimalkan dan 
mengintegrasikan kegiatan ekstrakurikuler keagamaan dengan mata pelajaran PAI. Beberapa kegiatan keagamaan didesain dengan mempertimbangkan waktu dan kebutuhan anak didik. Di samping itu, kegiatan keagamaan (mentoring) yang diintegrasikan dengan mata pelajaran PAI (MT-PAI) adalah wujud kegiatan konkret sebagai sarana untuk mewujudkan generasi yang yang berkarakter dan sumber daya manusia yang berakhlaqul karimah sebagai manifestasi dari upaya peningkatan ketakwaan terhadap Tuhan Yang Maha Esa.

\section{Rekomendasi}

1. Bagi sekolah sasaran; Pengembangan PAI melalui berbagai kegiatan, baik intrakurikuler maupun ekstra kurikuler keagamaan yang terintegrasi dengan mata pelajaran PAI perlu terus ditingkatkan, sehingga lingkungan sekolah yang religius yang ditandai dengan sikap dan perilaku yang dilandasi nilai-nilai agama (Islam) dari semua warga sekolah tetap terus terjaga, dan bahkan selalu meningkat. Karena dengan kondisi tersebut, benih-benih konflik maupun kekerasan antar warga sekolah dapat dicegah dan diminimalisir.

2. Kegiatan keagamaan yang terintegrasi dengan mata pelajaran PAI tersebut dapat dijadikan acuan bagi sekolah lain yang belum maksimal dalam pembelajaran PAI.

3. Apresiasi terhadap pimpinan sekolah yang mempunyai keberpihakan dan kepedulian terhadap PAI perlu diperhatikan oleh pihak terkait (Kementerian Agama, Pemerintah Daerah, dan pihak terkait)

\section{DAFTAR PUSTAKA}

An-Nahlawi, Abdurrahman (1989): Prinsipprinsip dan Metode Pendidikan Islam. Bandung, Diponegoro.

Azra, Azyumardi (2000). "Pendidikan Islam: Tradisi dan Modernisasi Menuju Milenium Baru". Jakarta, Logos Wacana Ilmu.

Baidhowi, Zakiyuddin (2005): Pendidikan Agama Berwawasan Multikultural.Jakarta, Airlangga.

Darajat, Zakiah (1992): Ilmu Pendidikan Islam. Jakarta, Bumi Aksara

(1995): Pendidikan Islam Dalam Keluarga. Jakarta, Ruhama

Departemen Agama, 2005. Al Qur'an dan Terjemahnya.

Departemen Pendidikan dan Kebudayaan (2003): Kamus Besar Bahasa Indonesia. Jakarta, Balai Pustaka.

Departemen Pendidikan Nasional, UndangUndang No. 14 tahun 2005 tentang Dosen dan Guru. Jakarta, Cipta Jaya

Draver, James (1986): Kamus Psikologi.Jakarta, Bina Aksara.

Fadjar, Malik, (2005): Holistika Pemikiran Pendidikan. Bandung, Raja Grafindo Persada. Malik, A. M.YY. (2007): Pura dan Masjid (Konflik dan Integrasi Pada Suku Tengger). Jakarta, Penamadani.

Martono, Nanang (2012): Kekerasan Simbolik di Sekolah (Sebuah Ide Sosiologi Pendidikan Pierre Bourdieu). Jakarta, Raja Grafindo Persada.

Moleong, Lexy (2000): Metodologi Penelitian Kualitatif. Bandung, PT. Remaja Rosdakarya.

Muhaimin (2001): Paradigma Pendidikan Islam. Bandung: Rosdakarya.

Mujib, Abdul, et al. (2008): "Ilmu Pendidikan Islam". Jakarta, Kencana.

Nata, Abuddin, Dr., H., MA (2001): Peta Keragaman Pemikiran Islam di Indonesia. Jakarta, PT. Raja Grasindo Persada. 
Pusat Bahasa, Departemen Pendidikan Nasional (2003): Kamus Besar Bahasa Indonesia. Jakarta: Balai Pustaka.

Rakhmat, Jalaluddin (1988): Psikologi Komunikasi. Bandung, Remadja Karya.

Robins, Stephen P. (1996): Perilaku Orgaisasi, Edisi Bahasa Indonesia, Alih Bahasa: Dr. Hadyana Pujatmaka. Jakarta, Prenhallindo.

Rosyidin, Dedeng (2009): Konsep Pendidikan Formal Persatuan Islam (Persis). Bandung.

Suparlan (2010): Pendidikan karakter: Sedemikian pentingkah dan apa yang harus kita lakukan (online)' (http://www. suparlan.com), diakses 15 Juni 2015.

Tafsir, Ahmad (2005): Ilmu Pendidikan Dalam Perspektif Islam. Bandung, PT. remaja Rosdakarya.

Thontowi, A. (2012): Hakkekat religiusitas (Online), (http://www.sumsel.kemenag. go.id, diakses tanggal 15 Juni 2015.
Undang-Undang No. 20/2003 tentang Sistem Pendidikan Nasional.

Wortman, Camille B. Elizabeth F.Loftus, Mary E.Marshall (1985): Psycology, New York, Alfred A.Kniff. Inc.

Zakiyuddin, Baidhowi (2005): Pendidikan Agama Berwawasan Multikultural.Jakarta, Airlangga.

Zuhaerini (1983): Metodik Khusus Pendidikan Agama, Surabaya: Usaha Nasional

http://kabar-pendidikan.blogspot. com/2011/04/budaya-religius-sekolah. html, 21 November 2014

www.kabar-pendidikan.blogspot.com,www. kmp-malang.com

www.arminaperdana.blogspot.com

http://sosialsosiologi.blogspot. com/2013/01/konflik-sosial.html, (Asiaaudiovisualra09gunawanwibisono's Blog) 